Journal of Clinical Investigation

Vol. 41, No. 6, 1962

\title{
BICARBONATE REABSORPTION IN THE DOG WITH EXPERIMENTAL RENAL DISEASE *
}

\author{
By PETER A. F. MORRIN, $\dagger$ W. BLRTON GEDNEY, LEONARD N. NEWMARK AND \\ NEAL S. BRICKER $\ddagger$ \\ (From the Department of Internal Medicine, Renal Division, Washington University School \\ of Medicine, St. Louis, Mo.)
}

(Submitted for publication January 9, 1962; accepted February 22, 1962)

In the metabolic acidosis of chronic progressive renal disease the urine usually contains little or no bicarbonate, and during the infusion of bicarbonate, reabsorption has been found to be within the normal range (1). A defect in base reabsorption consequently has not been emphasized as an important factor in the genesis of the acidosis. However, a recent study by Schwartz, Hall, Hays and Relman (2) indicated that such a defect could be demonstrated in some patients with chronic uremia if the lowered plasma bicarbonate concentrations were elevated to normal levels over a 2- to 3-day period by exogenous base administration. Prior to treatment these patients had chronic acidosis and excreted a bicarbonate-free urine. After therapy, significant bicarbonate excretion occurred and this continued until the arterial $\mathrm{pH}$ and plasma bicarbonate concentrations approached their pretreatment levels. The present studies were designed to investigate the patterns of bicarbonate reabsorption by diseased kidneys over a wide range of plasma bicarbonate levels, using as an experimental model the dog with one normal and one diseased kidney.

\section{METHODS}

Fourteen experiments were performed on 11 young adult female dogs weighing from 9 to $22 \mathrm{~kg}$. Ten animals had unilateral pyelonephritis (3), and one had unilateral aminonucleoside nephritis (4). In all studies simultaneous urine collections were made from both kidneys. The majority of experiments was performed on trained unanesthetized animals which had previously been subjected to a bladder-splitting procedure (5) ; how-

* Supported by the National Institutes of Health (Grant A-2667) and the Department of the Army, Research and Development Branch (Contract no. DA-49007-MD-772).

$\uparrow$ American Heart Association Research Fellow. $\$$ Established Investigator, American Heart Association. ever, four animals were studied after induction of anesthesia with sodium pentobarbital. In the latter group, the ureters were exposed through a midline abdominal incision, and urine was collected from polyethylene catheters inserted directly into the ureters. Blood was sampled continuously throughout each urine collection from an indwelling femoral arterial catheter. High rates of urine flow were attained by mannitol infusion in most instances, but water and urea diuresis were employed in selected experiments. In six experiments sodium bicarbonate was infused constantly at a single rate; in four studies potassium bicarbonate was infused constantly at a single rate; and in four studies the concentration of bicarbonate in the infusion fluid was increased stepwise on two or more occasions so as to produce a progressive elevation of plasma bicarbonate levels. In two of the latter experiments, the animals received $3 \mathrm{~g}$ of ammonium chloride orally on the day prior to study in order to provide low plasma bicarbonate levels during the initial clearance periods.

Urine and blood samples for $\mathrm{pH}$ and $\mathrm{CO}_{2}$ determinations were collected anaerobically under mineral oil. Measurements of $\mathrm{pH}$ were made with a Beckman model $\mathrm{G}$ $\mathrm{pH}$ meter at room temperature and all values were corrected to $37^{\circ} \mathrm{C}(6,7)$. Carbon dioxide content was determined by the method of Van Slyke and Neill (8). The carbon dioxide tension $\left(\mathrm{pCO}_{2}\right)$ was calculated from the Henderson-Hasselbalch equation. $\mathrm{A} \mathrm{pK}^{\prime}$ value of 6.10 and a value for $\alpha$ of 0.0301 were employed for plasma. The $\alpha$ value used for urine was 0.0309 and values for $\mathrm{pK}^{\prime}$ were calculated for each urine sample according to the formula $\mathrm{pK}^{\prime}=6.33-0.5 \sqrt{\mathrm{B}}$, where $\mathrm{B}$ represents the total cation concentration estimated as the sum of sodium plus potassium (9). Bicarbonate values were obtained by subtracting dissolved $\mathrm{CO}_{2}$ from total $\mathrm{CO}_{2}$ content. Net bicarbonate reabsorption was calculated in the conventional manner and is expressed in the text and tables as microequivalents per milliliter of GFR, rather than milliequivalents per $100 \mathrm{ml}$ of GFR. Bicarbonate excretion has been expressed in two ways: 1) excretion rate in microequivalents per milliliter of GFR (UV/GFR); and 2) the fraction of filtered bicarbonate excreted (UV/FL), where FL = filtered load. A Donnan factor of 1.05 was used in calculating filtered bicarbonate. Creatinine was measured by the method of Bonsnes and Taussky (10). Additional details of the experimental procedures have been described previously $(4,11)$. 
TABLE I

Bicarbonate reabsorption during constant infusion of sodium bicarbonate*

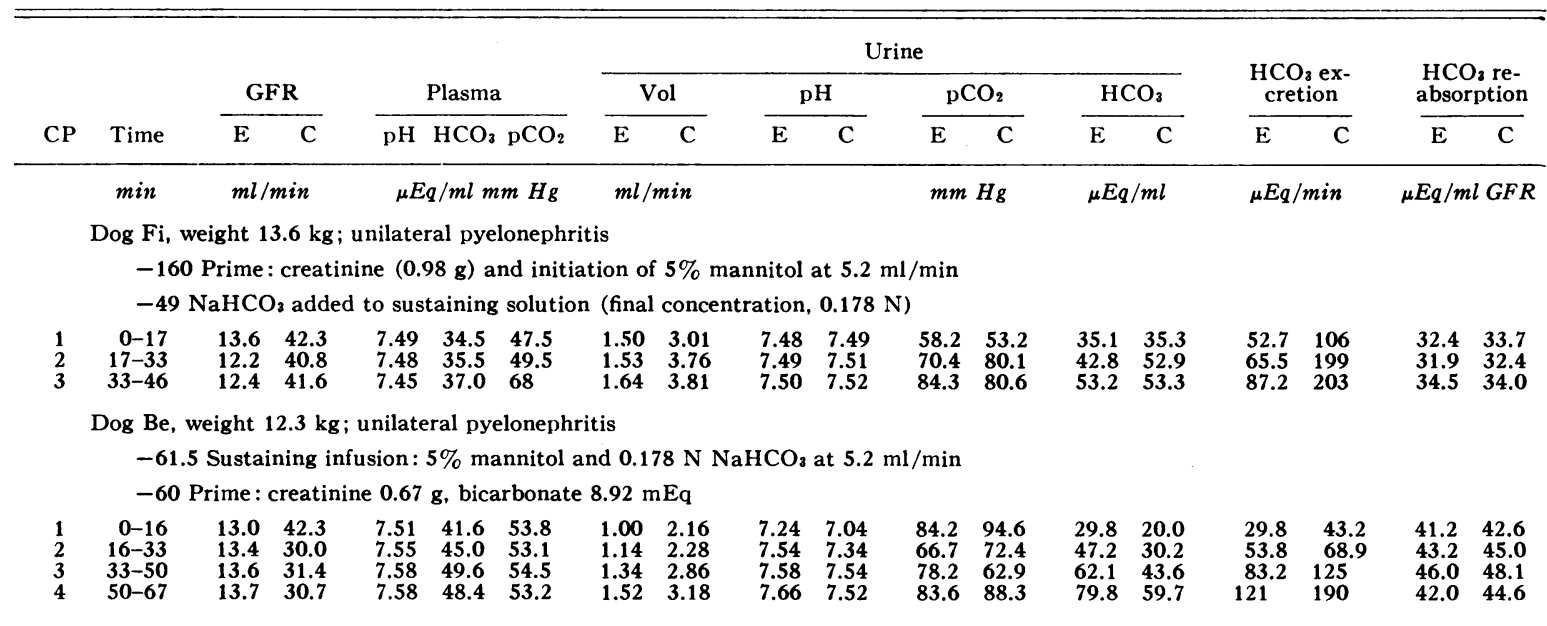

* A continuous infusion of creatinine $(7 \mathrm{mg} / \mathrm{min})$ and vasopressin $(1.6 \mathrm{mU} / \mathrm{min})$ was maintained throughout the experiments. $\mathrm{CP}=\mathrm{clearance}$ period, GFR = glomerular filtration rate, $\mathrm{E}=$ experimental kidney, $\mathrm{C}=$ control kidney.

\section{RESULTS}

In all experiments, data for the diseased kidneys have been compared with contemporaneous values for the contralateral control organs. Table I depicts the results of two experiments on animals receiving infusions of sodium bicarbonate at a constant rate. In both, the values for bicarbonate reabsorption by the diseased kidney were in the same range as those for the control organ, with the mean values for the diseased organs equalling 98.2 and 95.6 per cent, respectively, of those for the contralateral organs. The rates of reabsorption in dog Be were the highest observed in any of the studies, and would not appear to be explicable entirely by the moderate elevation of arterial $\mathrm{CO}_{2}$ tensions (12-14).

In Table II an experiment is shown for an animal pretreated with ammonium chloride in which plasma bicarbonate concentrations were raised from an initial level of 19.6 to $34.0 \mathrm{mEq}$ per $\mathrm{L}$.

TABLE II

Bicarbonate reabsorption during stepwise elevation of plasma bicarbonate *

\begin{tabular}{|c|c|c|c|c|c|c|c|c|c|c|c|c|c|c|c|c|}
\hline \multirow[b]{3}{*}{$\mathrm{CP}$} & \multirow[b]{3}{*}{ Time } & \multirow{2}{*}{\multicolumn{2}{|c|}{ GFR }} & \multirow{2}{*}{\multicolumn{3}{|c|}{ Plasma }} & \multicolumn{6}{|c|}{ Urine } & \multirow{2}{*}{\multicolumn{2}{|c|}{$\begin{array}{c}\mathrm{HCO}_{3} \mathrm{ex}- \\
\text { cretion }\end{array}$}} & \multirow{2}{*}{\multicolumn{2}{|c|}{$\begin{array}{l}\mathrm{HCO}_{3} \mathrm{re}- \\
\text { absorbed }\end{array}$}} \\
\hline & & & & & & & \multicolumn{2}{|c|}{$\mathrm{pH}$} & \multicolumn{2}{|c|}{$\mathrm{pCO}_{2}$} & \multicolumn{2}{|c|}{$\mathrm{HCO}_{3}$} & & & & \\
\hline & & $\mathrm{E}$ & $\mathrm{C}$ & $\mathrm{pH}$ & $\mathrm{HCO}_{3}$ & $\mathrm{pCO}_{2}$ & $\mathrm{E}$ & C & $\mathrm{E}$ & C & $\mathrm{E}$ & $\mathrm{C}$ & $\mathrm{E}$ & $\mathrm{C}$ & $\mathrm{E}$ & $\bar{C}$ \\
\hline & $\begin{array}{c}\min \\
\operatorname{Dog} \mathrm{Cl} \text {, we } \\
-54 \mathrm{~W} \\
-46 \mathrm{~S} \\
-43 \frac{1}{2}\end{array}$ & $\begin{array}{r} \\
\quad m l \\
\text { at } 15.4 \\
\text { ter loa } \\
\text { tainin } \\
\text { iming }\end{array}$ & $\begin{array}{l}\min \\
\mathrm{kg} ; \mathrm{u} \\
\mathrm{d} 250 \\
\text { infusi } \\
\text { injecti }\end{array}$ & $\begin{array}{r}\mu E \\
\text { ateral } \\
\\
: 5 \% \\
\text { of } 0.7\end{array}$ & $\begin{array}{l}\text { nannitol } \\
\mathrm{g} \text { creat }\end{array}$ & $\begin{array}{l}\mathrm{Hg} \\
\text { phritis } \\
\text { at } 5.2 \\
\text { inine }\end{array}$ & $\mathrm{nl} / \mathrm{min}$ & & $m m$ & $\mathrm{Hg}$ & $\mu E$ & $/ m l$ & $\mu E q$ & $\min$ & $\mu E q / m$ & $l G F R$ \\
\hline $\begin{array}{l}\mathbf{1} \\
\mathbf{2} \\
\mathbf{3}\end{array}$ & $\begin{array}{r}0-15 \\
15-28 \\
28-42\end{array}$ & $\begin{array}{l}20.8 \\
18.9 \\
19.8\end{array}$ & $\begin{array}{l}42.4 \\
39.8 \\
45.4\end{array}$ & $\begin{array}{l}7.36 \\
7.37 \\
7.45\end{array}$ & $\begin{array}{l}19.6 \\
19.5 \\
19.4\end{array}$ & $\begin{array}{l}35.8 \\
34.7 \\
28.8\end{array}$ & $\begin{array}{l}7.16 \\
7.35 \\
7.45\end{array}$ & $\begin{array}{l}7.21 \\
7.25 \\
7.35\end{array}$ & $\begin{array}{l}39.3 \\
28.5 \\
28.8\end{array}$ & $\begin{array}{l}37.5 \\
37.3 \\
37.4\end{array}$ & $\begin{array}{r}8.9 \\
10.2 \\
14.8\end{array}$ & $\begin{array}{l}10.3 \\
11.2 \\
14.5\end{array}$ & $\begin{array}{l}12.4 \\
12.4 \\
18.3\end{array}$ & $\begin{array}{l}22.8 \\
22.4 \\
30.9\end{array}$ & $\begin{array}{l}20.0 \\
19.8 \\
19.5\end{array}$ & $\begin{array}{l}20.0 \\
19.9 \\
19.7\end{array}$ \\
\hline \multicolumn{17}{|c|}{47 Infusion II : $5 \%$ mannitol plus $0.178 \mathrm{~N} \mathrm{NaHCO}$ at $5.2 \mathrm{ml} / \mathrm{min}$} \\
\hline $\begin{array}{l}4 \\
5 \\
6\end{array}$ & $\begin{array}{l}57-71 \\
71-85 \\
85-101\end{array}$ & $\begin{array}{l}21.5 \\
20.1 \\
19.9\end{array}$ & $\begin{array}{l}49.2 \\
46.9 \\
44.5\end{array}$ & $\begin{array}{l}7.45 \\
7.45 \\
7.45\end{array}$ & $\begin{array}{l}22.4 \\
25.1 \\
25.4\end{array}$ & $\begin{array}{l}33.2 \\
37.2 \\
37.6\end{array}$ & $\begin{array}{l}7.75 \\
7.76 \\
7.85\end{array}$ & $\begin{array}{l}7.46 \\
7.59 \\
7.74\end{array}$ & $\begin{array}{l}23.0 \\
30.5 \\
31.6\end{array}$ & $\begin{array}{l}47.7 \\
46.4 \\
43.8\end{array}$ & $\begin{array}{l}24.1 \\
33.5 \\
43.6\end{array}$ & $\begin{array}{l}25.6 \\
34.4 \\
46.9\end{array}$ & $\begin{array}{l}27.5 \\
36.5 \\
37.1\end{array}$ & $\begin{array}{l}48.4 \\
49.2 \\
79.7\end{array}$ & $\begin{array}{l}22.2 \\
24.5 \\
24.3\end{array}$ & $\begin{array}{l}22.5 \\
25.3 \\
24.9\end{array}$ \\
\hline \multicolumn{17}{|c|}{102 Infusion III : $5 \%$ mannitol plus $0.357 \mathrm{~N} \mathrm{NaHCO}_{3}$ at $5.2 \mathrm{ml} / \mathrm{min}$} \\
\hline $\begin{array}{l}7 \\
8 \\
9\end{array}$ & $\begin{array}{l}101-115 \\
115-130 \\
130-145\end{array}$ & $\begin{array}{l}19.8 \\
21.1 \\
21.8\end{array}$ & $\begin{array}{l}47.4 \\
41.5 \\
46.0\end{array}$ & $\begin{array}{l}7.48 \\
7.47 \\
7.47\end{array}$ & $\begin{array}{l}28.1 \\
31.8 \\
34.0\end{array}$ & $\begin{array}{l}39.0 \\
45.1 \\
48.3\end{array}$ & $\begin{array}{l}7.94 \\
8.00 \\
7.99\end{array}$ & $\begin{array}{l}7.83 \\
7.95 \\
8.00\end{array}$ & $\begin{array}{l}33.1 \\
45.5 \\
55.9\end{array}$ & $\begin{array}{l}46.6 \\
61.4 \\
68.0\end{array}$ & $\begin{array}{r}58.9 \\
97.3 \\
122.3\end{array}$ & $\begin{array}{r}64.3 \\
122.6 \\
163.1\end{array}$ & $\begin{array}{r}71.3 \\
149.8 \\
245.8\end{array}$ & $\begin{array}{l}132.5 \\
260.8 \\
450.2\end{array}$ & $\begin{array}{l}25.9 \\
26.3 \\
24.4\end{array}$ & $\begin{array}{l}26.7 \\
27.2 \\
25.9\end{array}$ \\
\hline
\end{tabular}

* Creatinine $(7 \mathrm{mg} / \mathrm{min})$ was infused continously throughout the experiment. See Table I for abbreviations. 
Bicarbonate reabsorption increased in a parallel fashion bilaterally; however, at each level of plasma bicarbonate, reabsorption tended to be slightly less in the diseased kidney.

The comparable order of magnitude noted in these three experiments for bicarbonate reabsorption by diseased and contralateral control kidneys has been observed in all animals studied, despite the fact that the severity of the renal lesion varied considerably among the different animals. (GFR for the diseased kidneys ranged from 28 to 85 per cent of the concurrent values for the control organs.) However, the differences between the kidneys depicted in Tables I and II were also found with consistency. These differences become more apparent when the data are expressed in terms of excretion rates rather than reabsorption rates. In Figure 1, the percentage of filtered bicarbonate excreted by each kidney is shown for an experiment in which plasma bicarbonate was elevated in a stepwise fashion. The values increased in a roughly parallel fashion bilaterally, but at all plasma concentrations, the diseased kidney excreted a greater fraction of its filtered bicarbonate. The comparison of excretion rates is presented in greater detail in Figure 2. In this graph, UV/FL values for the two kidneys are expressed as a ratio (i.e., UV/FL, diseased: UV/FL, control) and are plotted on the ordinate against plasma bicarbonate concentrations on the abscissa. Data are comprised of 78 individual clearance periods from the ten experiments in which sodium bicarbonate

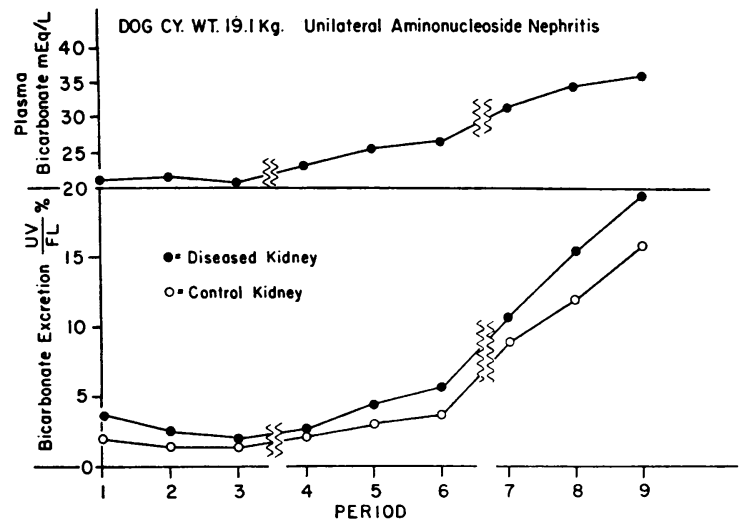

Fig. 1. Percentage of filtered bicarbonate exCRETED (UV/FL) IN DISEASED AND CONTRALATERAL CONTROL KIDNEYS DURING THE INFUSION OF SODIUM BICARBONATE.

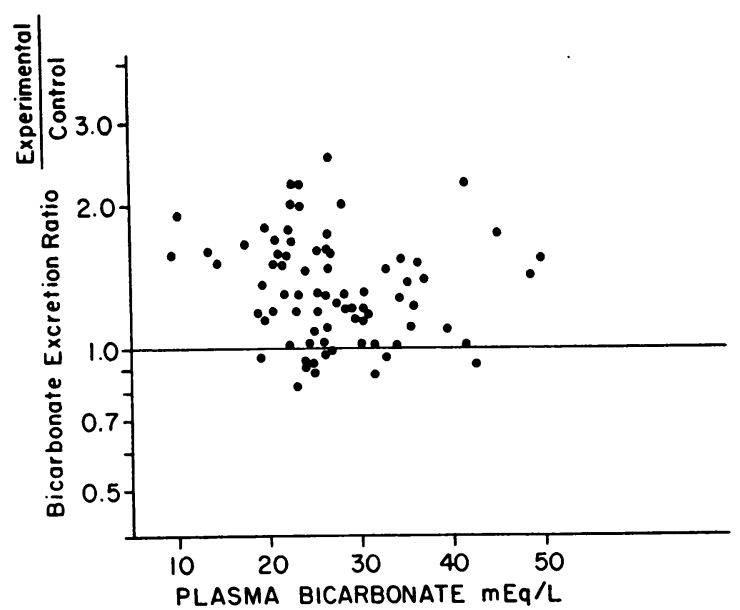

Fig. 2. Relationship between bicarbonate excreTION IN DISEASED AND CONTROL KIDNEYS AS A FUNCTION of plasma bicarbonate concentrations. The values on the ordinate represent the ratio of diseased to normal kidneys for the fraction of filtered bicarbonate excreted. A semilogarithmic scale has been used for the ordinate so that a twofold difference in either direction from the line of unity is reflected by an equal distance on the graph.

was infused. The great majority of points fall above the line of unity, demonstrating a greater rate of excretion of filtered bicarbonate by the diseased organs at all plasma bicarbonate levels ( $p$ in a paired $t$ test $<0.001)$. In Figure 3, values for the excretion ratios are plotted against arterial $\mathrm{pCO}_{2}$ values. Again the points lie predominantly above 1.0. It is of interest to note that the values for excretion ratios are independent of both plasma bicarbonate concentrations and the arterial $\mathrm{pCO}_{2}$ values.

In previous studies on animals with experimental unilateral renal disease, it has been noted that the diseased organ also excretes a greater fraction of filtered sodium than the contralateral control organ (15). An attempt was made, therefore, to examine the interrelationships between sodium and bicarbonate excretion in the animals of this study. For both ions the excretion rates per unit of GFR (i.e., UV/GFR) were greater for the diseased kidneys. Thus, the diseased kidneys excreted more sodium and more bicarbonate per milliliter of glomerular filtrate. By examining the differences in UV/GFR between the two kidneys (i.e., UV/GFR diseased - UV/GFR control, or $\Delta \mathrm{UV} / \mathrm{GFR}$ ), it is possible to compare the extra moiety of bicarbonate in the urine of the diseased 


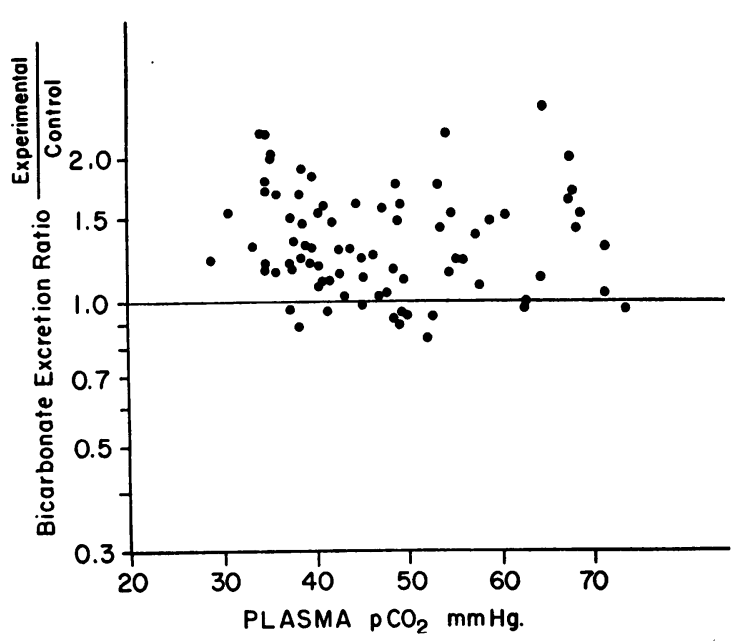

Fig. 3. Relationship Between bicarbonate exCreTION IN DISEASED AND CONTROL KIDNEYS AS A FUNCTION OF THE PARTIAL PRESSURE OF $\mathrm{CO}_{2}$ IN ARTERIAL BLOOD. See Figure 2 for explanation of the ratio employed for the ordinate.

organ with the extra moiety of sodium. The results of this comparison, shown in Figure 4, demonstrate a significant correlation between the $\Delta$ sodium and $\Delta$ bicarbonate terms $(\mathrm{p}<0.01)$. The distribution of the data indicates that the values for sodium tend to exceed those for bicarbonate and the regression line through the points (calculated by the method of least squares) has a slope of 0.41. Bicarbonate, therefore, cannot be the sole anion excreted in greater quantities by the dis-

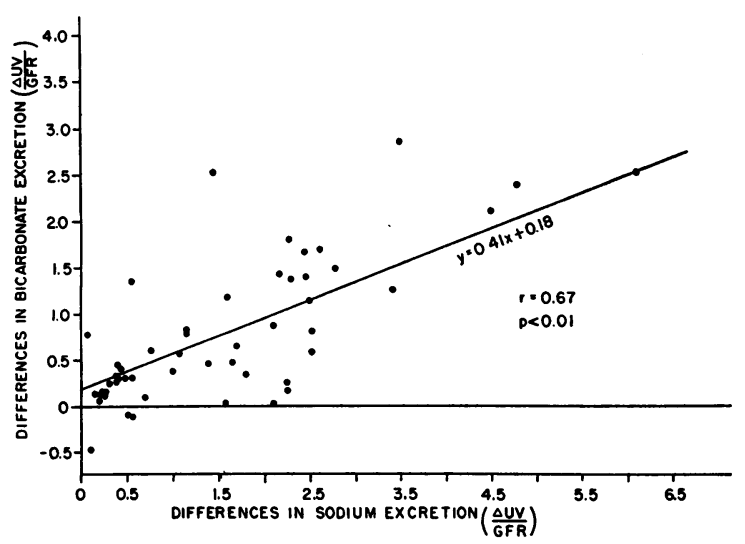

Fig. 4. Differences IN $\mathrm{HCO}_{3}^{-}$EXCRETION PER UNIT OF GFR BETWEen DISEASEd AND CONTROLS KIDNEYS AS A FUNCTION OF THE SIMULTANEOUS DIFFERENCES IN NA EXCRETION. $\triangle U V / G F R$ represents the UV/GFR value for the diseased kidney minus the simultaneous value for the contralateral control organ. eased organs, and in Figure 5 the values for $\Delta$ $\mathrm{UV}_{\mathrm{Na}} / \mathrm{GFR}$ are compared with those for $\Delta \mathrm{UV}_{\mathrm{Cl}} /$ GFR. A significant correlation also exists between those two parameters, and the slope of the regression line is 0.38 .

In Table III, the patterns of bicarbonate excretion are shown during the infusion of potassium bicarbonate. In these studies, potassium rather than sodium represented the predominant urinary cation. In each of the four experiments, bicarbonate reabsorption was closely comparable bilaterally. In three instances, the diseased kidney excreted a greater fraction of filtered bicarbonate than the control organ. One of these studies is shown in Table III, A. The fractions of filtered sodium and chloride excreted and the excretion rate of potassium relative to the filtered load were also greater for the diseased organ. In one ani-

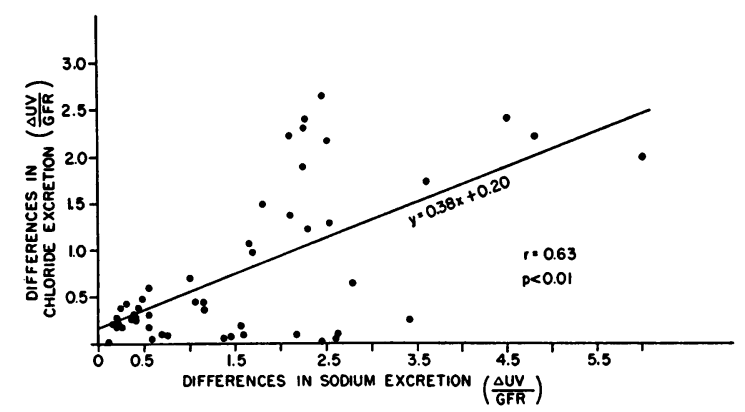

Fig. 5. Difference IN $\mathrm{CL}^{-}$EXCRETION PER UNit OF GFR BETWEEN DISEASED AND CONTROL KIDNEYS AS A FUNCTION OF THE SIMULTANEOUS DIFFERENCES IN NA EXCRETION. See Figure 4 for definition of $\Delta U V / G F R$.

mal, however (Table III, B), the experimental kidney excreted less of its filtered bicarbonate, whereas the excretion of sodium and chloride was greater. Unfortunately, the hemibladder draining the control kidney in this animal was found to be obstructed shortly after the study was completed and the experiment could not be repeated.

\section{DISCUSSION}

The comparison of bicarbonate excretion between the diseased and normal kidney is simplified in certain respects when the two organs reside in the same animal. Among the important variables that influence the renal regulation of bicarbonate, at least two may be assigned identical values for both kidneys at any point in time. These in- 
TABLE III

Bicarbonate, sodium, potassium, and chloride excretion during infusion of potassium bicarbonate *

\begin{tabular}{|c|c|c|c|c|c|c|c|c|c|c|c|c|c|c|c|c|c|}
\hline \multirow[b]{2}{*}{$\mathrm{CP}$} & \multirow[b]{2}{*}{ Time } & \multicolumn{4}{|c|}{ Plasma } & \multicolumn{2}{|c|}{ GFR } & \multicolumn{2}{|c|}{ V } & \multicolumn{2}{|c|}{$\begin{array}{c}\mathrm{HCO}_{3}^{-} \text {ex- } \\
\text { cretion } \\
\mathrm{UV} / \mathrm{FL} \\
\times 100\end{array}$} & \multicolumn{2}{|c|}{$\begin{array}{l}\mathrm{Na}^{+} \text {ex- } \\
\text { cretion } \\
\mathrm{UV} / \mathrm{FL} \\
\times 100\end{array}$} & \multicolumn{2}{|c|}{$\begin{array}{c}\mathrm{K}^{+} \text {excre- } \\
\text { tion } \\
\text { UV/FL } \\
\times 100\end{array}$} & \multicolumn{2}{|c|}{$\begin{array}{c}\mathrm{Cl}^{-} \text {excre- } \\
\text { tion } \\
\mathrm{UV} / \mathrm{FL} \\
\times 100\end{array}$} \\
\hline & & $\mathrm{pH}$ & $\mathrm{HCO}_{3}^{-}$ & $\mathrm{Na}^{+}$ & $\mathrm{K}^{+}$ & $\mathrm{E}$ & $\mathrm{C}$ & $\mathrm{E}$ & $\mathrm{C}$ & $\mathbf{E}$ & $\mathrm{C}$ & $\mathbf{E}$ & $\mathrm{C}$ & $\mathrm{E}$ & $\mathrm{C}$ & $\mathrm{E}$ & $\mathrm{C}$ \\
\hline & $\min$ & & $\underset{m l}{\mu E q /}$ & $\underset{m l}{\mu E q /}$ & $\begin{array}{c}\mu E q / \\
m l\end{array}$ & $m l /$ & $\min$ & $m l /$ & $\min$ & & & & & & & & \\
\hline \multirow[t]{2}{*}{ A } & \multicolumn{17}{|c|}{ Dog Se,† wt 13.2 kg; pyelonephritis } \\
\hline & \multicolumn{17}{|c|}{-47 Sustaining infusion: $20 \%$ urea and $0.1 \mathrm{~N}$ potassium bicarbonate } \\
\hline $\begin{array}{l}1 \\
2 \\
3 \\
4\end{array}$ & $\begin{array}{r}0-15 \\
15-31 \\
31-49 \\
49-62\end{array}$ & $\begin{array}{l}7.34 \\
7.41 \\
7.42 \\
7.42\end{array}$ & $\begin{array}{l}24.5 \\
25.0 \\
25.3 \\
26.1\end{array}$ & $\begin{array}{l}127 \\
120 \\
127 \\
127\end{array}$ & $\begin{array}{l}6.95 \\
7.95 \\
7.80 \\
7.45\end{array}$ & $\begin{array}{l}14.8 \\
14.6 \\
15.5 \\
14.7\end{array}$ & $\begin{array}{l}38.9 \\
35.1 \\
34.3 \\
34.3\end{array}$ & $\begin{array}{l}1.09 \\
1.24 \\
1.34 \\
1.46\end{array}$ & $\begin{array}{l}1.31 \\
1.54 \\
1.66 \\
1.96\end{array}$ & $\begin{array}{l}14.0 \\
20.1 \\
24.9 \\
25.6\end{array}$ & $\begin{array}{l}13.7 \\
18.5 \\
21.0 \\
23.0\end{array}$ & $\begin{array}{l}2.0 \\
2.9 \\
3.1 \\
3.8\end{array}$ & $\begin{array}{l}1.3 \\
2.3 \\
2.6 \\
3.4\end{array}$ & $\begin{array}{l}123.8 \\
124.2 \\
116.0 \\
150.2\end{array}$ & $\begin{array}{r}108.1 \\
104.6 \\
89.1 \\
106.6\end{array}$ & $\begin{array}{l}5.0 \\
5.6 \\
5.6 \\
6.1\end{array}$ & $\begin{array}{l}3.4 \\
4.0 \\
4.1 \\
4.4\end{array}$ \\
\hline \multirow[t]{2}{*}{ B } & \multicolumn{17}{|c|}{ Dog Ro, wt $11.3 \mathrm{~kg}$; pyelonephritis } \\
\hline & \multicolumn{17}{|c|}{-45.5 Sustaining infusion: $10 \%$ mannitol and $0.1 \mathrm{~N}$ potassium bicarbonate } \\
\hline $\begin{array}{l}1 \\
2 \\
3 \\
4 \\
5\end{array}$ & $\begin{array}{c}0-10 \\
10-21.5 \\
21.5-33 \\
33-42.5 \\
42.5-53\end{array}$ & $\begin{array}{l}7.27 \\
7.31 \\
7.32 \\
7.33 \\
7.32\end{array}$ & $\begin{array}{l}23.1 \\
24.1 \\
24.2 \\
25.0 \\
24.9\end{array}$ & $\begin{array}{l}140 \\
135 \\
136.3 \\
133.8 \\
132.5\end{array}$ & $\begin{array}{l}6.6 \\
6.8 \\
7.5 \\
8.0 \\
8.1\end{array}$ & $\begin{array}{l}14.3 \\
13.8 \\
13.4 \\
13.8 \\
12.9\end{array}$ & $\begin{array}{l}28.2 \\
26.7 \\
27.4 \\
26.5 \\
25.1\end{array}$ & $\begin{array}{l}2.29 \\
2.60 \\
2.74 \\
2.97 \\
3.13\end{array}$ & $\begin{array}{l}4.06 \\
4.49 \\
4.84 \\
5.16 \\
5.33\end{array}$ & $\begin{array}{l}16.8 \\
21.4 \\
23.7 \\
24.9 \\
30.3\end{array}$ & $\begin{array}{l}20.2 \\
22.7 \\
25.9 \\
27.9 \\
32.3\end{array}$ & $\begin{array}{r}7.65 \\
9.69 \\
10.11 \\
10.50 \\
11.85\end{array}$ & $\begin{array}{l}5.36 \\
6.82 \\
6.62 \\
7.66 \\
8.10\end{array}$ & $\begin{array}{l}125.7 \\
135.0 \\
138.6 \\
142.2 \\
140.9\end{array}$ & $\begin{array}{l}124.0 \\
143.2 \\
130.7 \\
146.2 \\
161.5\end{array}$ & $\begin{array}{l}11.2 \\
13.6 \\
14.0 \\
14.3 \\
16.7\end{array}$ & $\begin{array}{l}8.96 \\
10.7 \\
10.5 \\
11.7 \\
13.0\end{array}$ \\
\hline
\end{tabular}

* UV $=$ excretion rate/minute, FL = filtered load/minute. For other abbreviations, see Table I. Priming dose and sustaining infusion of creatinine as in previous experiments.

$t$ Dog Se was placed on a salt-free diet for 3 days prior to the experiment.

clude: 1$)$ the concentration of bicarbonate in the glomerular filtrate, and 2) the arterial $\mathrm{pCO}_{2}$. Under these conditions, the patterns of bicarbonate excretion of the experimentally diseased kidneys corresponded closely to those of the contralateral control organs. At normal to high plasma bicarbonate concentrations, the rate of reabsorption per unit of GFR was of the same order of magnitude for both kidneys; and when plasma concentrations were increased in a stepwise fashion over a wide range, reabsorption by the diseased kidney tended to increase in parallel with that of the control organ. Furthermore, in studies dealing with the acidifying capacity of the experimentally diseased kidney, bicarbonate reabsorption has been found to be virtually complete at low plasma bicarbonate concentrations (16). These data suggest that the mechanisms subserving bicarbonate reabsorption operated in an orderly and reproducible manner and remained appropriately responsive to changes in the acid-base characteristics of the perfusing blood.

Despite the similarities in function, however, a quantitative difference was observed between the two kidneys of individual animals. This was characterized by slightly lower values for bicarbonate reabsorption per unit of GFR by the diseased kidneys or, in terms of excretion, by higher values for $U V / G F R$ and $U V / F L$. The nature of this difference is of some interest and warrants brief discussion.

The mechanism underlying the difference must have certain specific characteristics if it is to satisfy the existing experimental data. 1) It must allow for continuing responsiveness of the bicarbonate reabsorptive system to changes in $\mathrm{pH}, \mathrm{pCO}_{2}$, and filtrate concentrations of bicarbonate. 2) It must allow for unimpeded and complete bicarbonate reabsorption during metabolic acidosis (16). 3) It must account for the slightly lower values for reabsorption of filtered bicarbonate by the diseased kidney at normal or intermediate concentrations of plasma bicarbonate, and yet permit rates of reabsorption at high plasma concentrations that exceed the total filtered load under the former conditions. 4) It must be independent of body fluid abnormalities that attend the uremic state, inasmuch as these were not present in the animals studied. 5) It must allow for unimpeded influx of hydrogen ions into tubular fluid under conditions of metabolic acidosis, since titratable acid and ammonium excretion rates per unit of GFR have been found to be virtually identical for experimentally diseased and contralateral control kidneys (16).

One event that might satisfy these conditions is a decrease in carbonic anhydrase activity in the tubular epithelial cells of the experimentally dis- 


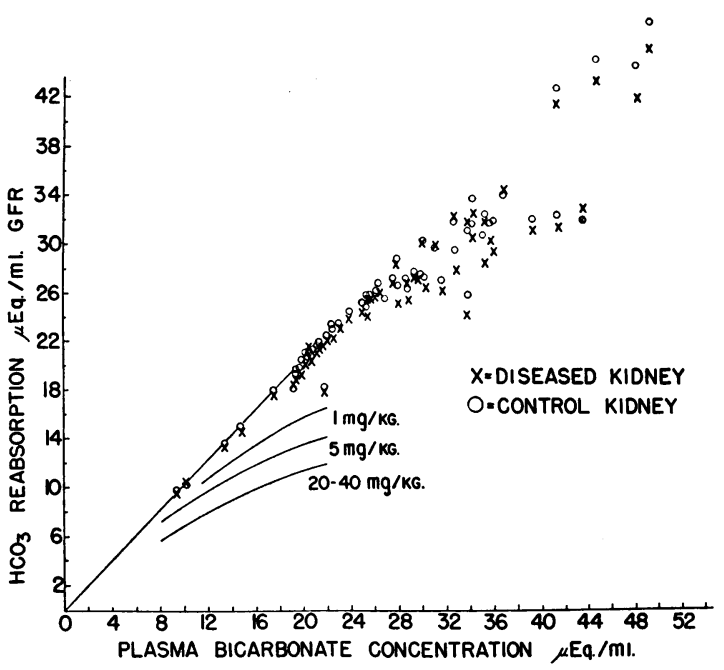

Fig. 6. BICARBONATE REABSORPTION IN DISEASED AND CONTRALATERAL CONTROL KIDNEYS AS A FUNCTION OF PLASMA BICARBONATE CONCENTRATION. The eight points in the upper right-hand portion of the graph are from the same $\operatorname{dog}(\operatorname{dog} \mathrm{Be}$, see Table I). The three lower lines are taken from the studies of Schwartz and associates (17), and the milligram per kilogram terms refer to the dosage of acetazolamide employed in these animals.

eased kidneys. ${ }^{1}$ Schwartz, Falbriard and Relman (17) recently have shown that when acetazolamide is administered acutely to dogs, bicarbonate reabsorption is suppressed despite the presence of metabolic acidosis; and the degree of suppression varies with the dosage of carbonic anhydrase inhibitor. In these studies the plot of bicarbonate reabsorption per unit of GFR versus plasma bicarbonate concentrations, provided a separate curvilinear function at each of three levels of carbonic acid inhibition (induced by 1.0, 5.0, and 20 to $40 \mathrm{mg}$ per $\mathrm{kg}$ of acetazolamide). When the reabsorption term was taken as the velocity of the reaction and the concentration term as the substrate concentration, each curve conformed to classic Michaelis-Menten enzyme kinetics, suggesting that in the presence of carbonic anhydrase inhibition the enzyme activity may represent a rate-limiting step in bicarbonate reabsorption.

In Figure 6, bicarbonate reabsorption has been plotted against plasma bicarbonate concentrations for all of the present experiments performed during

\footnotetext{
1 Schwartz and co-workers have developed this concept in an analysis of the patterns of bicarbonate excretion in uremic patients; their discussion may be consulted for reference (2).
}

$\mathrm{NaHCO}_{3}$ infusion. For the group data, the points for the diseased kidneys cannot be distinguished from those of the control organs. The three curves obtained by Schwartz and co-workers (17) are included for comparison. Using a Lineweaver-Burk plot, the linear regression line through the points for the diseased kidneys could not be differentiated statistically from the regression line for the control kidneys $(p>0.7)$, whereas both functions differed appreciably from those of the acetazolamide-treated groups. ${ }^{2}$ These observations suggest, therefore, that any suppression of carbonic anhydrase activity in the experimentally diseased kidneys would be less than that observed at the lowest level of enzyme inhibitor employed in the normal dogs.

There is at least one other explanation that would appear to satisfy the limiting conditions imposed by the experimental data. This would account for the differences in bicarbonate excretion between the two kidneys on the basis of associated differences in other ionic excretion patterns and would not require a specific defect in the system for bicarbonate reabsorption. It has been noted that under all conditions in which the diseased kidneys excreted more bicarbonate relative to GFR, they also excreted more sodium (and more chloride). Furthermore, the difference in excretion rates between the two kidneys for sodium exceeded that simultaneously observed for bicarbonate (i.e., $\Delta \mathrm{UV}_{\mathrm{Na}} / \mathrm{GFR}>\Delta \mathrm{UV}_{\mathrm{HCO}_{3}} / \mathrm{GFR}$ ). While a primary defect in bicarbonate reabsorption could account for some of the extra sodium excreted by diseased kidneys, it could not account for all of it; nor could it account entirely for the extra moiety of chloride. ${ }^{3}$ However, a primary change in the pattern of sodium excretion in the nephrons of the diseased kidney might explain the accom-

2 The regression line for the diseased kidneys is described by the equation $y=0.0054+0.905 x \quad(\mathrm{r}=0.98)$; while that for the control kidneys has the form $y=0.0045$ $+0.91 x \quad(\mathrm{r}=0.99)$. In comparing these equations with those presented by Schwartz and associates (17), the intercepts for the acetazolamide-treated dogs must be decreased by a factor of 10 , owing to the use of different dimensions for the coordinates in the two studies.

${ }^{3}$ A limited increment in sodium chloride excretion might be explicable on the basis of an osmotic diuretic effect of the unreabsorbed bicarbonate; however, UV/GFR values for both sodium and chloride are also greater in the diseased kidney during complete bicarbonate reabsorption. 
panying changes in both bicarbonate and chloride excretion patterns. Thus, when sodium chloride and bicarbonate are the predominant ionic species in the urine, the excretion of a greater amount of sodium (per unit of GFR) must be accompanied by a corresponding increment in the sum of the two anions. If carbonic anhydrase activity were unaltered, and the capacity to transfer hydrogen ions from cell water to tubular fluid were unimpaired, complete bicarbonate reabsorption might still occur at decreased plasma bicarbonate concentrations. Chloride would then be the anion accompanying the extra sodium remaining in the tubular fluid of the diseased kidney. Conversely, at elevated plasma bicarbonate concentrations, the extra sodium could then be accompanied by both bicarbonate and chloride, with the relative amounts of each depending, at least in part, upon the acidbase properties of the perfusing blood. ${ }^{4}$ In order

${ }^{4}$ This argument may also be presented in terms of reabsorption: A decrease in the fraction of filtered sodium reabsorbed in the diseased kidney (whether due to a decrease in the absolute rate of $\mathrm{Na}^{+}$reabsorption per nephron or to an increase in filtered load per nephron) would be associated with a corresponding decrease in the percentage of filtered $\mathrm{Cl}^{-}+\mathrm{HCO}_{3}^{-}$reabsorbed. The relative rates of $\mathrm{HCO}_{3}^{-}$versus $\mathrm{Cl}^{-}$reabsorption would then depend in large measure upon the fraction of reabsorbed sodium ions that exchanges for hydrogen ions. The latter statement would also apply to the normal kidney. When the reabsorptive mechanism for bicarbonate is grossly unsaturated (i.e., low bicarbonate concentrations in the filtrate), complete bicarbonate reabsorption would be expected bilaterally. However, under conditions in which bicarbonate is incompletely reabsorbed (higher $\mathrm{HCO}_{3}^{-}$concentrations in the filtrate), the rates of hydrogen ion secretion in the diseased and normal kidneys might be similarly proportional to the respective rates of sodium reabsorption. This proportionality would vary in both kidneys with the acid-base characteristics of the perfusing blood and might only involve that portion of hydrogen ion influx occurring passively in consequence of an electrochemical gradient. Nevertheless, a decrease in sodium reabsorption, relative to the filtered load, in the nephrons of the diseased kidney could, in the context of this hypothesis, account for the observed differences in bicarbonate (and chloride) reabsorption. A similar explanation could be invoked if the $\mathrm{Na}$ reabsorption per milliequivalent of filtered sodium were equal bilaterally, and the passive leak of sodium ions back into the tubular fluid were greater in the diseased kidney. Under these conditions, the passive influx of sodium ions would tend to dissipate the intratubular electrical negativity and would thereby diminish the electrochemical gradient for hydrogen ions. to explore this possibility further, the relationships between $\Delta \mathrm{UV}_{\mathrm{Na}} / \mathrm{GFR}, \Delta \mathrm{UV}_{\mathrm{K}} / \mathrm{GFR}, \Delta \mathrm{UV}_{\mathrm{HCO}_{:} / \text {/ }}$ GFR, $\Delta \mathrm{UV}_{\mathrm{Cl}} / \mathrm{GFR}$, and arterial $\mathrm{pH}$ were examined statistically, using partial correlation methods (18). These analyses were designed to indicate what combination of variables would yield the best fit for the observed data. The results were expressed in terms of $\mathrm{R}^{2}$, the multiple coefficient of determination. In the studies in which sodium bicarbonate was infused, the linear relationship between the $\Delta$ sodium and $\Delta$ bicarbonate terms provided an $\mathrm{R}^{2}$ value of 0.54 . This indicates that 54

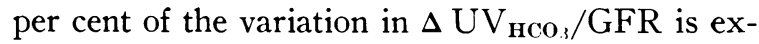
plained by variation in $\Delta \mathrm{UV}_{\mathrm{Na}} / \mathrm{GFR}$. Given a value for $\Delta$ sodium and $\Delta$ potassium, the $\mathrm{R}^{2}$ value increased to 0.58 . However, given the value for $\Delta$ sodium and arterial $\mathrm{pH}, \Delta$ bicarbonate can be predicted at a 0.68 level $\left(\mathrm{R}^{2}=0.68\right)$. The predictability of $\Delta$ bicarbonate is not further increased if the $\Delta$ potassium term is added to the $\Delta$ sodium and $\mathrm{pH}$ values (i.e., $\mathrm{R}^{2}=0.68$ ). Similar analyses have been performed for the experiments in which potassium bicarbonate was infused. For any give values for $\Delta$ sodium and $\Delta$ potassium, the $\mathrm{R}^{2}$ value for $\Delta$ bicarbonate is 0.62 . However, when the $\mathrm{pH}$ term is included with $\Delta$ sodium and $\Delta$ potassium, 85 per cent of the variation in $\Delta$ bicarbonate may be explained (i.e., $R^{2}=0.85$ ). In view of the complexity of the system under study, these data are believed to support the contention that $\Delta \mathrm{UV}_{\mathrm{Na}} / \mathrm{GFR}$ and arterial $\mathrm{pH}$ are two major physiologic determinants of $\Delta \mathrm{UV}_{\mathrm{HCO}_{3}} / \mathrm{GFR}$. During potassium bicarbonate infusion, $\Delta \mathrm{UV}_{\mathrm{K}} /$ GFR plus the $\Delta \mathrm{Na}$ and $\mathrm{pH}$ terms will largely determine the value for $\Delta \mathrm{UV}_{\mathrm{HCO}_{3}} / \mathrm{GFR}$.

The degree to which the present observations on animals with experimentally induced unilateral renal disease may be extrapolated to humans with chronic bilateral renal disease and uremia cannot yet be determined. In the latter situation, the total number of functioning nephrons (considered as a fraction of the original number) is reduced to a much greater degree than in the experimental model. Because of this, any adaptive changes in nephron function might be expected to be more exaggerated. In addition, the uremic alterations in body fluid composition could influence the patterns of bicarbonate reabsorption. However, it is our intention, by using an experimental model 
with one diseased and one control kidney, to diminish these variables and thereby to improve the opportunity of evaluating intrinsic functional capabilities of the surviving nephrons. It is of interest to note, therefore, that in the diseased kidney of the experimental model, as in uremic man: 1) bicarbonate may be reabsorbed completely at low plasma concentrations ; 2) net reabsorption increases appropriately during bicarbonate infusion; and 3) bicarbonate reabsorption differs quantitatively from that of the (contralateral) normal kidney. The direction of this difference is the same as that observed when uremic patients in whom plasma bicarbonate concentrations are raised to normal are compared with individuals free of renal disease (2).

\section{SUMMARY}

Studies of bicarbonate excretion were performed in dogs with experimentally induced unilateral renal disease and values for the diseased kidneys were compared with simultaneous values for the contralateral kidneys, which were maintained free of disease. Plasma concentrations of bicarbonate were varied over a wide range by infusing sodium or potassium bicarbonate solutions. Under any given set of experimental conditions, arterial $\mathrm{pH}$, arterial $\mathrm{pCO}_{2}$, and the bicarbonate concentration of the glomerular filtrate could be assigned identical values for the two kidneys. The patterns of bicarbonate reabsorption in the diseased kidneys were qualitatively similar to those of the control kidneys during both constant and rising plasma bicarbonate concentrations. However, a quantitative difference between the two kidneys was observed consistently. This was characterized by the excretion of a slightly greater fraction of the filtered bicarbonate by the diseased organ. The diseased kidney also excreted a greater fraction of filtered sodium and of filtered chloride. While an acquired intrinsic tubular defect in bicarbonate reabsorption cannot be excluded, the experimental observations seem to support the view that the quantitative differences in bicarbonate excretion are interrelated with, and probably dependent upon, the mechanisms responsible for the differences in sodium excretion.

\section{ACKNOWLEDGMENTS}

Many of the statistical analyses included in the text were performed on an IBM-650 computer. The authors are deeply indebted to Richard A. Dammkoehler, Director of Computing Facilities, Washington University, for his cooperation and collaboration in this effort.

\section{REFERENCES}

1. Roberts, K. E., Randall, H. T., Vanamee, P., and Poppell, J. W. Renal mechanisms involved in bicarbonate absorption. Metabolism 1956, 5, 404.

2. Schwartz, W. B., Hall, P. W., III, Hays, R. M., and Relman, A. S. On the mechanism of acidosis in chronic renal disease. J. clin. Invest. 1959, 38, 39.

3. Bricker, N. S., Dewey, R. R., and Lubowitz, H. Studies in experimental pyelonephritis: Simultaneous and serial investigation of a pyelonephritic and intact kidney in the same animal. Clin. Res. 1958, 6, 292.

4. Bricker, N. S., Stokes, M. J., Lubowitz, H., Dewey, R. R., Bernard, H. R., and Hartroft, P. M. Experimentally induced permanent unilateral renal disease in dogs. J. Lab clin. Med. 1958, 52, 571.

5. Desautels, R. E. Hemisection of the bladder for the collection of separate urine samples. Gynéc. et Obstét. 1957, 105, 767.

6. Rosenthal, T. B. The effect of temperature on the $\mathrm{pH}$ of blood and plasma in vitro. J. biol. Chem. 1948, 173, 25.

7. Wesson, L. G., Jr. Effect of temperature change on the $\mathrm{pH}$ of human urine. J. appl. Physiol. 1952-53, 5, 619.

8. Van Slyke, D. D., and Neill, J. M. The determination of gases in blood and other solutions by vacuum extraction and manometric measurement. I. J. biol. Chem. 1924. 61, 523.

9. Hastings, A. B., and Sendroy, J., Jr. The effect of variation in ionic strength on the apparent first and second dissociation constants of carbonic acid. J. biol. Chem. 1.925, 65, 445.

10. Bonsnes, R. W., and Taussky, H. H. On the colorimetric determination of creatinine by the Jaffé reaction. J. biol. Chem. 1945, 158, 581.

11. Bricker, N. S., Straffon, R. A., Mahoney, E. P., and Merrill, J. P. The functional capacity of the kidney denervated by autotransplantation in the dog. J. clin. Invest. 1958, 37, 185.

12. Relman, A. S., Etsten, B., and Schwartz, W. B. The regulation of renal bicarbonate reabsorption by plasma carbon dioxide tension. J. clin. Invest. 1953, 32, 972.

13. Brazeau, P., and Gilman, A. Effect of plasma $\mathrm{CO}_{2}$ tension on renal tubular reabsorption of bicarbonate. Amer. J. Physiol. 1953, 175, 33.

14. Dorman, P. J., Sullivan, W. J., and Pitts, R. F. The renal response to acute respiratory acidosis. J. clin. Invest. 1954, 33, 82. 
15. Bricker, N. S., Kime, S. W., Jr., Morrin, P. A. F., and Orlowski, T. The influence of glomerular filtration rate, solute excretion and hydration on the concentrating mechanism of the experimentally diseased kidney in the dog. J. clin. Invest. 1960, 39, 864.

16. Morrin, P. A. F., Bricker, N. S., Kime, S. W., Jr., and Klein, $\mathrm{C}$. Observations on the acidifying ca- pacity of the experimentally diseased kidney in the dog. J. clin. Invest. 1962, 41, 1297.

17. Schwartz, W. B., Falbriard, A., and Relman, A. S. An analysis of bicarbonate reabsorption during partial inhibition of carbonic anhydrase. J. clin. Invest. 1958, 37, 744.

18. Bennett, C. A., and Franklin, N. L. Statistical Analysis in Chemistry and the Chemical Industry. New York, Wiley, 1954. 